\title{
Erratum to: Inclusive probability of particle creation on classical backgrounds
}

\author{
Peter Kazinski ${ }^{\mathrm{a}}$
}

Physics Faculty, Tomsk State University, Tomsk 634050, Russia

Published online: 19 October 2020

(C) The Author(s) 2020

Erratum to: Eur. Phys. J. C. (2020) 80:734

https://doi.org/10.1140/epjc/s10052-020-8317-8

In the published version of this article, formulas (140) and (142) were improperly corrected.

The corrected formulas are as follows:

$$
\begin{aligned}
& \operatorname{det}\left[\bar{\Phi} \Phi^{T}\left(1-\epsilon \tilde{P}^{T} X \tilde{P} X^{\dagger}\right)\right] \\
& =\operatorname{det}\left[1+\epsilon \bar{\Phi} \Phi^{T}\left(P^{T} X \tilde{P} X^{\dagger}+X P X^{\dagger}\right)\right] \\
& =\operatorname{det}\left[1+\epsilon \Phi^{T} P^{T}\left(\Phi^{-1}\right)^{T} \Psi^{\dagger} \tilde{P} \Psi+\epsilon \Psi^{\dagger} P \Psi\right] \\
& =: \operatorname{det}(1+\Omega), \\
& \operatorname{det}(1+\Omega)=e^{\operatorname{Sp} \Omega} \operatorname{det}_{2}(1+\Omega) \\
& =e^{\epsilon \operatorname{Sp}\left(2 \Psi^{\dagger} P \Psi-\Phi^{T} P^{T}\left(\Phi^{-1}\right)^{T} \Psi^{\dagger} P \Psi\right)} \operatorname{det}_{2}(1+\Omega),
\end{aligned}
$$

Open Access This article is licensed under a Creative Commons Attribution 4.0 International License, which permits use, sharing, adaptation, distribution and reproduction in any medium or format, as long as you give appropriate credit to the original author(s) and the source, provide a link to the Creative Commons licence, and indicate if changes were made. The images or other third party material in this article are included in the article's Creative Commons licence, unless indicated otherwise in a credit line to the material. If material is not included in the article's Creative Commons licence and your intended use is not permitted by statutory regulation or exceeds the permitted use, you will need to obtain permission directly from the copyright holder. To view a copy of this licence, visit http://creativecomm ons.org/licenses/by/4.0/.

Funded by SCOAP ${ }^{3}$.

The original article can be found online at https://doi.org/10.1140/ epjc/s10052-020-8317-8.

a e-mail: kpo@phys.tsu.ru (corresponding author) 